\title{
大豆の粉砕・圧扁処理に伴うトリプシンインヒビター熱 安定性の增大
}

\begin{abstract}
盛永宏太郎*
Thermal Stabilization of the Trypsin-Inhibitor by Crushing -Flaking of Soybeans

Koutarou MORINAGA*

*Toyama College, 444, Gankaiji, Toyama-shi, Toyama 930-0193

The author had evaluated the digestion of proteins of parched soybeans by trypsin and observed high digestibility after parching of intact whole soybeans but very low digestibility after parching of crushed soybeans, previously this was because the trypsin inhibitor (TI) that is present in intact whole soybeans is readily inactivated by parching, whereas the TI in crushed soybeans has become thermostable and is not inactivated by parching. In this paper, changes in TI activity after tissue destruction and heating of soybeans were evaluated. The TI activity in parched $\left(150^{\circ} \mathrm{C}, 20 \mathrm{~min}\right.$. $)$ intact whole soybeans was decreased by heat to about $1 / 20$ of the initial level. On the other hand, TI activity in soybean flour or soybean flakes was less inactivated with a higher degree of tissue destruction. The TI activity in parched soybean flour with a particle diameter less than $1 \mathrm{~mm}$ was similar to that in raw soybeans. Proteins in raw soybeans, parched intact whole soybeans, and parched soybean flour were digested with trypsin. The digestion rate increased with the added amount of trypsin even when the amount of trypsin was lower than the unit amount of the residual TI. The digestion rate reached about $50 \%$ with an amount of trypsin the same as the unit amount of $\mathrm{TI}$ and increased thereafter in proportion to the added amount of trypsin, being the maximum with an amount of trypsin twice the unit amount of $T I$. (Received Oct. 16, 2001 ; Accepted Jan. 7, 2002)
\end{abstract}

筆者はトリプシンによる焙煎大豆のタンパク質消化を 調べて，大豆を無傷の状態で焙煎したときのタンパク質 の消化は良いが, 粉砕後に焙煎した大豆のタンパク質は 消化が非常に悪いことを見出しだ．そしてこの原因と して, 無傷の大豆に存在するトリプシン・インヒビター （以後 TI と記す）は焙煎することにより容易に熱失活す るのに対して, 破碎大豆の TI は熱安定性が增して焙煎 処理では熱失活しなくなることを認めだ2. そこで，大 豆組織をどの程度破壊すると TI の熱安定性が增すかな どについて調べた結果, 興味ある知見を得たので以下に その詳細を報告する。

\section{実 験 方 法}

\section{1. 試 料}

供試大豆 : 市販完熟乾燥丸大豆 (平成 10 年度・栃木 県産 : タチナガ八) を購入し，無傷で健全なもの（以下， 丸大豆と記す）を選別して使用した，その一般成分組成 は Table 1 に示した.

破砕大豆 : 丸大豆をブレンダーで粒径 $1 \mathrm{~mm}$ 末満にま で破砕して実験に供した，また，別に破砕して，粒径 2 $\mathrm{mm}$ 以上 $5 \mathrm{~mm}$ 末満のむの, $1 \mathrm{~mm}$ 以上 $2 \mathrm{~mm}$ 末満のも の, $0.6 \mathrm{~mm}$ 以上 $1 \mathrm{~mm}$ 末満のむの, $0.6 \mathrm{~mm}$ 末満のむの に篩別し，実験に供した.

圧扁大豆 : 丸大豆の厚みの $3 / 4$ に圧扁したもの（縁に 亀裂が生じる程度)，2/4に圧扁したもの，1/4 に圧扁し

\footnotetext{
* 富山短期大学（干930-0193 富山市願海寺 444）
} 
Table 1 Composition of soybean*

\begin{tabular}{lc}
\hline \multicolumn{1}{c}{ Composition } & Content $(\%)$ \\
\hline Water & 11.6 \\
Ash & 4.6 \\
Protein & 31.6 \\
Lipid & 20.6 \\
Carbohydrate & 31.6 \\
\hline
\end{tabular}

*: "Tachinagaha" of Japanese soybean.

たもの (油分が浸み出る程度) の各圧扁大豆を作成した。

\section{2. 焙煎処理}

筆者は先に, $150^{\circ} \mathrm{C}$ で焙煎した大豆のタンパク質の消 化は良好であるが, $120^{\circ} \mathrm{C}$ では加熱温度が不足して消化

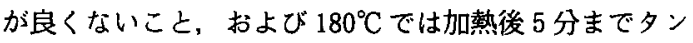
パク質の消化は急激に向上するが，その後は褐変などの 影響により時間の経過と共に消化が悪くなることを報告 した1).

そこで，大豆の各試料は $150^{\circ} \mathrm{C}$ に調整した熱風循環式 定温乾燥機に入れて 20 分間加熱した。 なお加熱が均一 になるように，丸大豆や圧扁大豆は互いに重ならないよ うにし，また破砕大豆は大豆 1 粒の厚さより厚くならな いようにして，アルミ製トレーに入れて加熱した，加熱 後, 各々焙煎大豆は乳鉢に移し微粉になるまで磨砕して から以下の実験に供した、またはさらにエーテルを用い て脱脂した後に実験に供した。

\section{TI 活性测定}

焙煎破砕脱脂大豆粉末 $100 \mathrm{mg}$ に $40^{\circ} \mathrm{C}$ に加温した Clark-Lubs $の \mathrm{pH}$ 緩衝液（pH7.6: 以後 CL 液と記す） $10 \mathrm{ml}$ を加えて均質化し， $40^{\circ} \mathrm{C}$ で 1 時間振とうしてから 遠心分離し，この上澄液を試料原液とした。

TI 活性值は $\mathrm{N}-\alpha$ - benzoyl - DL - arginine - p nitroanilide を用いるKAKADE らの方法”で求めた.

\section{4. トリプシン消化試験}

焙煎破砕脱脂大豆粉末を $100 \mathrm{mg}$ 遠沈管に取り，所定 量のトリプシンを含む CL 液 $25 \mathrm{ml}$ 加えて䍐濁した. 防 腐のためにトルェンを 1 滴加えた後, $37^{\circ} \mathrm{C} 20$ 時間放置 して大豆のタンパク質を消化した．消化後，20\%トリク ロル酢酸 $5 \mathrm{~m} l$ 加えて遠心分離し，沈殿区分を未消化大 豆タンパク質，上澄液区分を既消化大豆タンパク質上見 なして，各々の窒素量をケルダール法で求めた.

\section{実験結果及ひ考察}

\section{1. 焙煎破䃏大豆の TI 活性}

破砕の程度を変えた各破砕大豆を焙煎して TI 失活の 程度を調べ，その結果を Table 2 に示した.

大豆を無傷の丸大豆の状態で焙煎すると TI はよく失 活して，TI 活性值は生大豆の約 $1 / 20$ に低下することは すでに報告した2).

焙煎した破砕大豆の TI は，破砕の程度が増すほど熱 安定性が増して失活しなくなった。粒径を $2 \mathrm{~mm}$ 以下に まで破砕して焙煎した破砕大豆の TI はほとんよ゙熱失活 せず，その值は生大豆の TI 活性の約 $80 \%$ に相当した.

粒径 $1 \mathrm{~mm}$ 以下に破砕した大豆を顕微鏡で観察すると (Fig. 1)，細胞顆粒は散乱して，大豆種子の組織細胞は 壊滅的な破壊を受けていた。

このことから，大豆種子中の TI は大豆が無傷の状態 で存在する場合は熱失活しやすいが, 組織破壊を受ける とその程度に応じて熱安定性が増すものと思われた.こ の理由については, 次項の 2 の結果之合わせて考察す る.

日本の伝統食品である“きなこ”や“炒り豆”は無傷 の丸大豆を焙煎したすのである，従ってこれらのTI 熱失活するので，そのタンパク質の消化は良い゙)思わ れる. しかし，あらかじめ破砕した大豆は，本報の結果 から見て，焙煎してもTI は熱失活せず，消化が非常に

Table 2 TI activity in parched soybean flour

\begin{tabular}{|c|c|c|c|c|}
\hline \multicolumn{4}{|c|}{ Samples (particle diameter) } & \multirow{2}{*}{$\frac{\mathrm{TI}(\mathrm{unit} / \mathrm{mg})^{*}}{4.6 \pm 0.7}$} \\
\hline \multirow{5}{*}{$\begin{array}{c}\text { Parching } \\
\left(150^{\circ} \mathrm{C}, 20 \mathrm{~min}\right)\end{array}$} & \multicolumn{3}{|c|}{ Intact soybeans } & \\
\hline & & coarse & $(5-2 \mathrm{~mm})$ & $39 \pm 3$ \\
\hline & Crushed & medium & $(2-1 \mathrm{~mm})$ & $62 \pm 8$ \\
\hline & soybeans & fine & $(1-0.6 \mathrm{~mm})$ & $61 \pm 7$ \\
\hline & & powder & $(<0.6 \mathrm{~mm})$ & $67 \pm 12$ \\
\hline \multicolumn{4}{|c|}{ Control (raw soybeans) } & $75 \pm 8$ \\
\hline
\end{tabular}




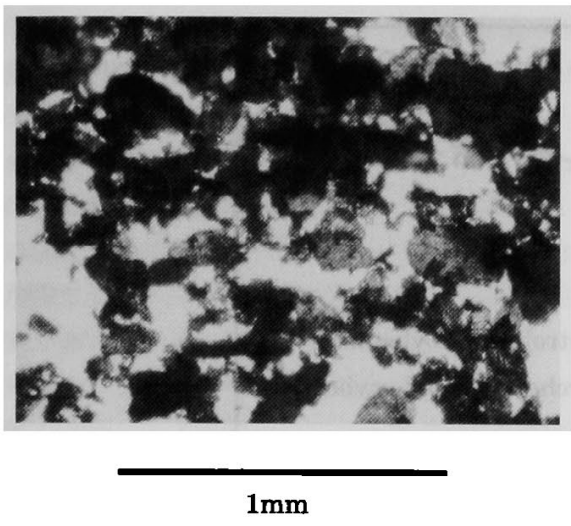

Fig. 1 Crushed soybean

Table 3 TI activity in parched soybean flakes

\begin{tabular}{clc}
\hline \hline \multicolumn{2}{c}{ Samples (degree of thickness) } & TI (unit/mg)* \\
\hline \multirow{3}{*}{ Parching } & Intact soybeans (4/4) & $2.4 \pm 1.3$ \\
$\left(150^{\circ} \mathrm{C}, 20 \mathrm{~min}\right)$ & Soybean flakes $(3 / 4)$ & $12.0 \pm 1.6$ \\
& Soybean flakes $(2 / 4)$ & $20.3 \pm 3.8$ \\
& Soybean flakes $(1 / 4)$ & $35.0 \pm 0.8$ \\
\hline Control (raw soybeans) & $71.7 \pm 3.4$ \\
\hline & $*:(\mathrm{n}=3)$
\end{tabular}

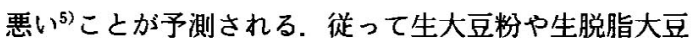
粉などを利用するときは，TI 熱失活するために加水 後に加熱する ${ }^{6)}$ な゙の特別の処置を行う必要があると思 われた.

\section{2. 焙煎圧扁大豆の TI 活性}

組織破壊亡 Tl の加熱安定性の関係を調べる目的で, 圧扁の程度を変えた各圧扁大豆を焙煎して，TI 活性を 測定しそその結果を Table 3 に示した。

大豆組織を丸大豆の厚みの $3 / 4 \sim 1 / 4$ に押し潰した後 に焙朔加熱すると，TI はその圧扁の程度に応じて熱安 定性が増し，TI は熱失活しなくなった。

この結果は前項の焙煎破砕大豆に同じく，大豆種子の 組織破壊と共に TI 熱安定性が増大することを示してい ろ.

以上の結果を考察するに当たって， CARMER らは7) TI 分子内に存在するSS 結合のブリッジを還元した後, 再 び元にむどすと，この TI は活性を取り戻すと報告して

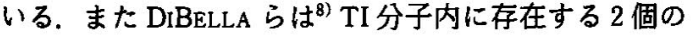
SS 結合の内の 1 個は TI の活性維持に不可欠であると 報告している。そしてまた， KITABATAKE らは99)大豆の
11Sや7S タンパク質は共存する水分が多量の場合はそ の水分量に影響を受けないが，少量の場合は水分量が少 なくなるのに比例して熱変性しないと報告している，本 報の場合あ大豆を組織破壊すればそれだけ大豆中の $\mathrm{TI}$ が空気酸化を受けやすくなり，また共存する水分も蒸発 しやすくなるなどが考えられる．本報の組織破壊と TI の熱安定性の試験結果もこのような影響を受けるものと 推測できるが，具体的な検討については稿を改めて報告 したい.

3. 焙煎大豆タンパク質のトリプシン消化

トリプシン添加量と TI が残存する焙煎大豆タンパク 質の消化との関係を調べ，その結果をFig. 2 に示した.

焙煎丸大豆は TI の大部分が失活してその活性は極端 に小さい，それ故に少量のトリプシンを添加するだけで 焙煎丸大豆のタンパク質は良く消化されるようになっ た。しかし，消化液中に残存する TI 単位に等しい量を 添加しても消化率は $50 \%$ 程度であった．TIの 2 倍の単 位量を添加してようやく消化率は約 80\%になった。

破碎大豆の TI は丸大豆中の TI と違って焙前加熱し ても熱失活せず，生大豆並の活性を維持する．従ってこ の生大豆と焙煎破砕大豆のタンパク質をトリプシンで消 化するには共存する TI に相当する多量のトリプシンを 必要とした，そしてこの生大豆と焙煎破砕大豆について もトリプシン添加量が消化液中に共存する TI 量に等し い単位量になったときにタンパク質の消化率が約 $50 \%$ になった．そしてTI量の約 2 倍量のトリプシン添加で 消化率が約 70\%になった．また，トリプシンを2 倍量以 上に過剩添加しても，焙煎丸大豆ほどの良好な消化率に はならなかった。

TI はトリプシンと 1 対 1 の関係で結合してトリプシ ンの消化作用を阻害するといわれている ${ }^{10)}$. 従って TI 活性の測定時に観察されるようにトリプシンの添加量が 試料液中の TI 量に達するまではタンパク質は消化され ないものと思ったが，本報の結果は TI 単位量よりトリ プシンの添加量が少量であってもその添加量に比例して TI と共存する基質タンパク質が消化することを示した. これは消化時間が TI 活性測定時のように分単位の短時 間ではなく，20 時間むの長時間をかけて消化したことが 影響したあのと思われた．また，共存する TI の単位と 等量のトリプシンの添加で大豆タンパク質の消化が約 $50 \%$ に達し，このタンパク質を充分に消化するには TI の約 2 倍量以上のトリプシンの添加を必要としたことも 含めて, これらはいずれる棚橋ら ${ }^{11)}$ が報告している TI とトリプシンとの親和力の影響が消化時間を長く取った 


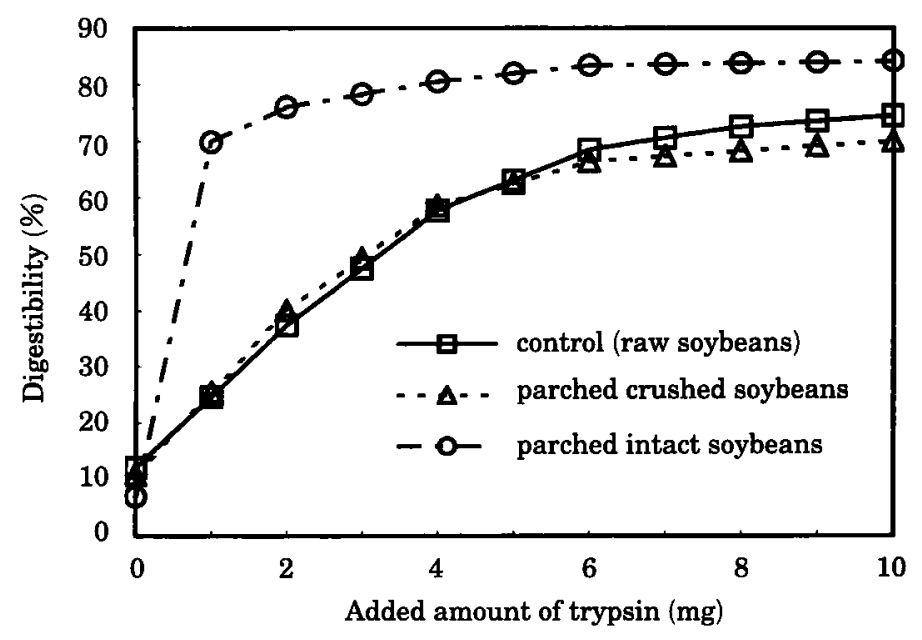

Fig. 2 Trypsin digestion of parched soybeans

Defatted soybean samples $(100 \mathrm{mg})$ were suspended in $0.05 \mathrm{M}$ phosphate buffer solution ( $\mathrm{pH} 7.620 \mathrm{ml}$ ) and digested with trypsin at $37^{\circ} \mathrm{C}$ for $20 \mathrm{~h}$.

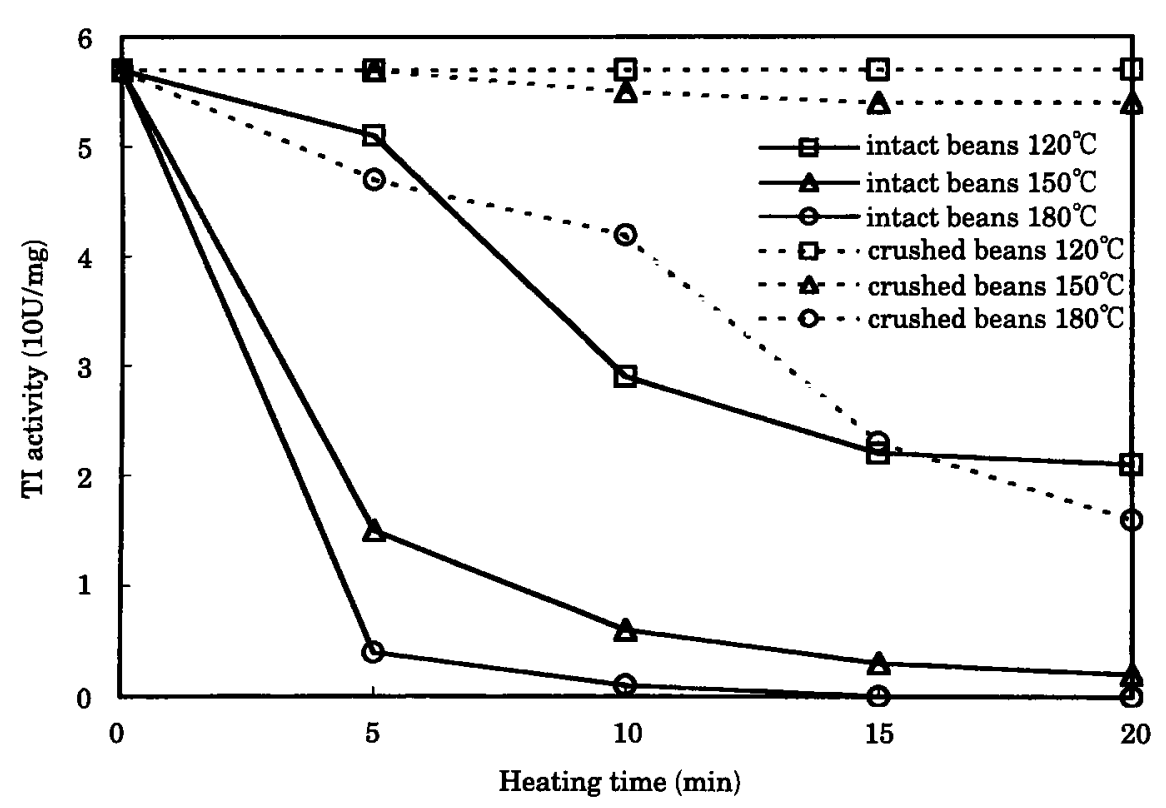

Fig. 3 Serial changes in soybean TI activity during parching

\section{ことで顕在化したあのと思われた。}

\section{4. 焙煎したときの大豆 TI の経時変化}

丸大豆及び破砕大豆を $120^{\circ} \mathrm{C}, 150^{\circ} \mathrm{C}, 180^{\circ} \mathrm{C}$ で焙煎し て TI 活性値の経時変化を調べその結果を Fig. 3 に示し た. $120^{\circ} \mathrm{C}$ の加熱では, 比較的容易に熱失活する無傷の丸 大豆でも TI は充分には失活せず，20 分間加熱で TI 活 性はわずかに $1 / 3$ 程度の減少であった。破砕大豆はこの 温度ではまったく失活しなかった。

$150^{\circ} \mathrm{C}$ に加熱すると，丸大豆は加熱 5 分間で TI 活性 
が1/5にまで急激に減少した。 その後も活性值は減少し て加熱 20 分後の TI 活性值は生大豆の $1 / 20$ になった。 破䂽大豆のこの温度での TI 失活は前項 1 でむ示した通 り,わずかであった。

$180^{\circ} \mathrm{C}$ にまで加熱温度を上げると，丸大豆の TI は 15 分でほぼ完全に活性を失った。しかしこの温度の加熱で は, 加熱 5 分で大豆はすでに褐変して，以後も時間之共 に褐変が進行して黒く焦げた状態になった：そしてこの 大豆のタンパク質のトリプシン消化は, 基質タンパク質 の過度の加熱による変性のために, 加熱時間が長いほど 悪くなることはすでに報告しだ)

$180^{\circ} \mathrm{C}$ 加熱の破砕大豆は, 20 分加熱後に TI 活性值は 約 1/3にまで咸少した。しかしこの破䂽大豆は過度の加 熱で焦げた状態になりタンパク質も不消化性になる。 そ れ故に TI が失活してあ $180^{\circ} \mathrm{C}$ 焙煎破砕大豆のタンパク 質のトリプシン消化は良くない!

要 約

（1）乾燥丸大豆を破碎後に焙煎して，TI 活性の変化 を調べたところ, 無傷の大豆の TI 活性は熱失活して $1 / 20$ 程度に低下したが, 破砕して微細になった大豆はど TI は熱安定性を増して熱失活しなくなった。粒径 $1 \mathrm{~mm}$ 以下に破砕した大豆の TI 活性值は未加熱大豆の TI 活 性に近い高い值を示した。

また，乾燥大豆を圧扁してから焙煎してその TI 活性 の変化を調べたところ, 破碎の場合之同様に, 薄く圧扁 した大豆の TI ほど熱失活せず TI 活性は高い値になっ た.

これは破砕または圧扁処理により，大豆細胞が破壊さ れたためにTI が熱安定性を増したものと思われた。

(2) 生大豆および焙煎丸大豆, 焙煎破碎大豆のタンパ ク質をトリプシンで消化したところ，三者共にトリプシ ン量が残存する TI 単位量以下の少量であっても, その トリブシン添加量に応じて消化率は徐々に向上し，TI 単位量に達したときに消化率は約 $50 \%$ になった，その 後もトリプシンの添加量に比例して消化率が向上した。 添加トリプシン量が TI 単位量の約 2 倍になったときに 消化率はほぼ最大值に近くなった。

また，焙煎丸大豆のタンパク質は TI 活性が低いので 少量のトリブシン量で良く消化するのに対して, 生大豆
と焙煎破碎大豆は TI 活性が高いために消化が悪く、多 量のトリプシンを加えないと消化率は良くならなかっ た.

(3) 焙煎大豆の TI 失活に及ぼす焙煎温度と時間の影 響を調べたところ， $120^{\circ} \mathrm{C}$ 加熱では温度が低く，無傷の 丸大豆です TI 失活は不充分であった．破碎大豆 TI は まったく失活しなかった. $150^{\circ} \mathrm{C}$ 加熱の丸大豆は加熱 10 分後にTI 活性値は $1 / 10$ に減少し, 20 分後には $1 / 20$ に なった。 $150^{\circ} \mathrm{C}$ 加熱の破砕大豆の $\mathrm{TI}$ は 20 分後でもわず かに $10 \%$ 減少しただけだった. $180^{\circ} \mathrm{C}$ 加熱の丸大豆は加 熱 5 分で TI 活性値が $1 / 10$ に隇少した. しかしこのとき の大豆は黒変して焦げた状態になった，破砕大豆の TI は $180^{\circ} \mathrm{C}$ 加熱であなお幾分活性を持続し 20 分後の值は 生の約 1/5を示した。

終わりに臨み，本研究の遂行に終始ご教示ご指導を睗 りました東京農業大学名誉教授・前川昭男博士，聖徳大 学教授・江指隆年博士, 東京農業大学教授・田所忠弘博 士に感謝申し上げます，また英文要旨の校閲を睗りまし た富山短期大学教授・児玉博英博士に深謝致します。

\section{文献}

1）盛永宏太郎: 食科工，44，219（1997）.

2）盛永宏太郎：食科工，46，352（1999）。

3) KaKade, M.L., Simons, N. and Liener, I.E.: Cereal Chem. 46, 518 (1969).

4）渡辺篤二・海老根英雄・太田輝夫 : 大豆食品（光 琳書院，東京), p. 204 (1971).

5）林寛・有山 恒 栄養之食糧, 10, 134, (1957).

6) Albrecht, W.J., Mustakas, G.C. and McGhee, J.E. : Cereal Chem., 43, 400 (1966).

7) CARMer, N. and BohaK, Z. : Israel J. Chem., 6, 1 (1968).

8) Dibella, F.L. and Liener, I.E. . J. Biol. Chem., 244, 2824 (1969).

9) Kitabatake, N., Tahara, M. and Doi, E. : Agric. Biol. Chem., 53, 1201 (1989).

10) Kunitz, M. : J. Gen. Physiol., 30, 291 (1947).

11）棚橋勝道・高野勝己・松本信二・鴨居郁三・小原 哲二郎：日食工誌，35，541（1988）。

(平成 13 年 10 月 16 日受付, 平成 14 年 1 月 7 日受理) 